\title{
THE EFFECTS OF NANOTECHNOLOGY INVESTMENTS ON COSTS
}

\section{DOI: 10.17261/Pressacademia.2015414374}

\section{Yavuz Turkan'}

'Bingol University. yturkan@bingol.edu.tr

\section{Keywords}

Nanotechnology, investment, cost, R\&D

econometrical analysis

\section{JEL Classificcation}

G24, M41, Z23

\begin{abstract}
With the revolutions in the dimension of the science, human needs are steadily changing. The developments, discoveries and inventions, which could not be imagined by those having lived in the previous centuries, are still seen as insufficient in the technology era we live in. That's why new technologies are being researched. The fundamental one of these new technologies is described as nanotechnology introduced as the new discovery of today. Nanotechnology is considered a fertile farm for the enterprises; therefore they focus on this technology for investment. In order to capture the market, maximize the value and profit and gain economic and politic power, both states and enterprises are trying to obtain this technology via their accomplished R\&D investments as soon as possible. Therefore, the very essential effects of nanotechnology investments on costs are researched. In addition, several financial and econometrical analyses are applied on some enterprises that are registered in Borsa Istanbul (Istanbul Stock Exchange), and that carry out nanotechnology investments. As a result of the analyses, it is stated that the costs of the products obtained by nanotechnology operations are decreased, that there is a negative relation between investments and costs of sales, and that there are increases in selling capacity of the enterprises through this kind of investments.
\end{abstract}

\section{NANOTEKNOLOJI YATIRIMLARININ MALIYETLERE ETKISI}

\section{Anahtar Kelimeler}

Nanoteknoloji, yatırım maliyet, AR-GE,

ekonometrik analiz

\section{JEL Sınıflandırması}

G24, M41, Z23

\section{ÖZET}

Bilimin boyut değiştirmesiyle birlikte insanların intiyaçları değişmekte, önceki çağlarda yaşayan insanların hayaline gelmeyecek gelişmeler, keşifler ve icatlar bile içinde bulunduğumuz teknoloji çağında yetersiz görülerek yeni teknolojiler araştırılmaktadır. Bu yeni teknolojilerin temeli de nanoteknoloji olarak tanımlanmış ve günümüzün yeni keşfi olarak ortaya çıkmıștır. Nanoteknoloji işletmeler için verimli bir tarla olarak telakki edilmiş ve işletmelerin yatırım çalışmaları bu teknolojiye odaklanmıştır. Piyasayı ele geçirmek, değer ve kârı maksimize etmek, ekonomik ve politik bir güç kazanmak için gerek devletler gerekse işletmeler yapmış oldukları Ar-Ge yatırımlarıyla bu olguyu biran önce elde etmeye çalışmaktadırlar. Bu nedenle çalışmada son derece önemli olan nanoteknoloji yatııımlarının maliyetlere etkisi araştııımış ve Borsa İstanbul'da yer alan ve nanoteknoloji yatııımları yapan bazı işletmeler üzerine çeşitli finansal ve ekonometrik analizler uygulanmıştır. Yapılan analizler neticesinde nanoteknolojik çalışmalar sonucu elde edilen ürünlerin maliyetleri düşürdüğü, yapılan yatııılarla satışların maliyeti arasında negatif bir ilişkinin olduğu ve bu tür yatııımlar sayesinde işletmelerin satış hacimlerinde artışların olduğu tespit edilmiştir. 


\section{GiRiş}

Bu çalışmada nanoteknoloji yatırımlarının maliyetlere etkisi ele alınacaktır. Başlamadan önce "Cırt Cırt" ürününün icadı ve mucidinin hikâyesi anlatılacaktır. George de Mestral amatör bir dağcı olarak 1948 yılında doğa yürüyüşü için köpeğiyle yürüyüşe çıkar. Bu esnada dikenli yapışkan bitkilerin köpeğinin tüylerine ve üzerindeki pantolon ve elbiselerine yapıştığını ve çıkmadığını görür. Doğa yürüyüşünden sonra eve gelir ve bu bitkileri inceler, mikroskop ile yakından bakınca bitkilerin kumaşa girip çengel şeklinde yapıştığını görür. Bunun sonucunda aklına birbirine yapışan bant yapma fikri gelir. Mesrtal icadını bir ayakkabı fabrikasında ayakkabıların bağcık yerine cırt cırt bandının kullanılmasını önerir fakat bu öneri fabrika yönetimi tarafından önemsenmez. Aynı şekilde gittiği çanta fabrikasından da olumlu sonuç alamaz. Fakat bu icat Japon firması tarafından öğrenilip benimsenir ve kendisine patent başvurusu dahi yapılır. İcadı Japon firmalarının sayesinde birçok üründe kullanılır hale gelir ve Velcro adında bir şirket kurar. Milyonlarca iş yapmaya başlayan şirket halen faaliyetlerini sürdürmektedir. NASA uzay merkezide bu icadı benimsemiş ve uzay giysileri dahil birçok üründe kullanmaya başlamıştır (http://www.organikmakale.com). Bu hikâyeden yola çıkarak diyebiliriz ki, işletmeler önlerine çıkan fırsatları çok iyi değerlendirmelidirler. Aynen öylede işletmeler içinde fırsatlar zincirini oluşturan nanoteknolojinin iyi bir şekilde kullanılması durumunda, üretilecek bir ürünle hem rakiplerinin önüne geçmiş, hem satış hacmini yükseltmiş ve hem de küreselleşen dünyada kendine bir yer bulmuş olacaktır.

Yukarıda ifade edilen hikâyeye benzer bir şekilde doğadan esinlenerek yeni bir ürün üretip büyüyen şirketlerden biri de Naksan Holding'dir. Suyun üzerinde yaşamasına rağmen su iticilik özelliğine sahip olan nilüfer (lotus) çiçeğinden esinlenen Naksan Holding şirketi nanoteknoloji yatırımları ile Atlas Halı markasını üretmiştir. Bu halılar bu teknoloji sayesinde, tıpkı nilüfer çiçeğinin yapraklarında olduğu gibi, su iticilik özelliği ile leke barındırmama, ışık etkisiyle kendi kendini temizleyebilme, küf, bakteri, mayt ve mantar barındırmama ve doğal iletkenlik özelliği ile vücuttaki statik elektriği alarak stresin azalmasına yardımcı olma gibi özelliklere sahiptir. 1,2 Milyon TL'lik bir Ar-Ge çalışmasının ürünü olan bu nano halılar sayesinde işletme cirosunu yüzde 350 büyüterek nanoteknolojiye yapılacak yatırımların ve icad edilecek ürünlerin işletmeler açısından ne derece önemli olduğunu ortaya koymaktadır (http://www.haberler.com).

Çalışmada son derece önemli olan nanoteknoloji yatırımlarının, özellikle maliyetlere etkisi araştırılmaktadır. Öncelikle nanoteknoloji kavramına değinilmekte, dünyada ve Türkiye'de yapılan nanoteknoloji yatırımları ele alınmaktadır. Daha sonra nanoteknoloji yatırımlarının maliyetleri etkilediğine dair yapılan açıklamalar ifade edilmekte, bununla birlikte ulusal pazarda yer alan ve nanoteknoloji yatırımları yapan beş imalat işletmesinin ( AKIN TEKSTIL A.Ş., AKSA AKRILIK KIMYA SANAYii A.Ş., ARÇELIK A.Ş., DYO BOYA FABRIKALARI SANAYI VE TICARET A.Ş. ve VESTEL ELEKTRONIK SANAYI VE TICARET A.Ş.) verileri kullanılarak şirketlerin yapmış oldukları yatırımları temsil eden Ar-Ge yatırımlarının Net Satışlar ve Satışların Maliyeti ile olan ilişkisi Korelasyon analizine tabi tutulmuş daha sonra işletmenin satış hacmini gösteren Net Satışlarla yapılan yatırımlar arasında bir etkileşimin olup olmadığı, yapılan yatırımların satışları etkileyip etkilemediğinin tespit edilmesi amacıyla regresyon analizi uygulanmıştır. Son olarak çalışmada öncelikli gayemiz olan yapılan nanoteknoloji yatırımlarının maliyetlere etkisinin ortaya çıkarılması amacıyla Ar-Ge Yatırımlarının ve Satışların Maliyetinin Satışlara oranının tespiti amacıyla dikey analiz 
yapılmış ve daha sonra elde edilen sonuçlar 2005 yılı baz yıl alınarak trend analizine tabi tutulmuştur.

\section{NANOTEKNOLOJI KAVRAMI}

Son yıllarda nano birçok alanda hayatımıza girmeye başlamıştır. Önüne veya sonuna geldiği kelimeye ilgi çekici bir mana kazandırmaktadır. Nano, önümüzdeki yıllarda hayatımızın vazgeçilmez bir parçası olmaya adaydır.

Nanoteknoloji, atomların tek tek kullanılarak; makro dünyada olmayan niteliklere sahip aygıtların üretilmesi ve kullanılması alanıdır. Türkçeye "moleküler üretim" diye çevrilebilecek olan nanoteknoloji kavramı, gittikçe adından daha çok söz ettirmektedir (www.yaklasansaat.com). Kendi kendini temizleyen boyalar, kirlenmeyen kumaşlar, bakterileri öldürdüğünden dolayı kokmayan çoraplar, mikrop barındırmayan buzdolapları, tek şarbon mikrobunu bile algılayabilen sensörler, esnek ama daha dayanıklı kaplamalar, kanserli hücrelerin vücuda zarar vermeden öldürülmesini sağlayan cihazlar, günlerce etkisini kaybetmeyen kremler gibi birçok ürünle hayatımıza girmeye başlayan nanoteknoloji, yeni bir teknoloji devrimi olarak algılanmaktadır.

Nanoteknoloji bir yandan eski teknolojilere yeni bakış açıları getirirken diğer yandan da, daha önemli ve kritik olan, önceleri imkânsız gibi gözüken yeni teknolojilere ve uygulamalara kapı aralamaktadır. Örnek olarak; malzemelerin özellikleri nanoteknoloji sayesinde daha iyi anlaşılmakta, dolayısıyla bu malzemelerin kullanıldığı uygulamalarda geliştirilmektedir. Öte yandan, nano seviyede işlevselleştirilmişnano parçacıklarla kanserli dokuların yok edilmesi ancak nanoteknolojiyle mümkün hale gelmektedir. Önümüzdeki yıllarda nanoteknolojinin birçok alan için ne kadar vazgeçilmez olduğu daha da iyi anlaşılmaya başlanacaktır. Günümüzde üretilmiş olan nanoteknolojik ürünlerle gelecekte özellikle sağlık, savunma, tekstil, enerji, elektronik ve fotonik gibi alanlarda elde edilecek katma değeri yüksek ürünlerin insanoğlunun hayatını daha da kolaylaştırması beklenmektedir.

Kimyasal ve fiziksel özellikler, yapının büyüklüğüne ve atom geometrisinin ayrıntılarına, sonradan bağlanan yabancı bir atomun cinsine ve bağlanma geometrisine göre çok farklı ve olağanüstü davranışlar sergilemektedir. Örneğin, mevcut nano yapıya yabancı bir atomun yapışması; elektrik iletkenliğini fark edilebilir şekilde değiştirmektedir. Bu yabancı atom geçiş elementi olduğunda yapıştığı bir nanoyapıya manyetik özellikler kazandırabilmektedir (Grupta, 2003: 470).

Kısaca; bir nanoyapının fiziksel özellikleri, bağ yapısı ve dolayısı ile mukavemeti onun büyüklüğüne ve boyutlarına bağlı olarak önemli değişimler gösterebilmektedir. Nanoteknoloji ya yeni malzemeler, nanoyapılar tasarlayıp sentezlemeyi, ya da mevcut nanoyapıları veya molekülleri işlevsel hale getirip onların kazandıkları olağanüstü özellikleri yeni uygulamalarda kullanmayı amaçlamaktadır (Grupta, 2003: 469). Bir başka ifadeyle nanoteknoloji, bilinen molekülleri yeni atom ve moleküller ekleyerek işlevsel duruma sokmakta veya kuvantum noktaları, telleri ve tüpler gibi yapay yapıları tasarlayıp sentezlemektedir. Bu şekilde sentezlenen yapılar çok aktif olmakta ve önemli kimyasal süreçlere aracılık etmektedirler ve böylece olağanüstü elektronik veya manyetik özellikler sergilemektedirler. Nanoteknoloji bilinen bütün teknolojilere kıyasla çok daha fazla temel bilim ve kuramsal araştırmalara gereksinim duymaktadır (Grupta, 2003: 469). 


\subsection{Nanoteknolojinin Tanımı}

Nanoteknoloji, aşırı küçük yapısal maddelerin üretimi, araştırılması ve bunlardan yararlanmanın teknikleri üzerinde çalışmaktadır. "Nano" sözcüğü Yunancadan alınmıştır ve "Cüce" anlamına gelmektedir. Nanoteknoloji çeşitli şekillerde tanımlanabilmektedir. Nanoteknoloji, atomik ve moleküler boyutlardaki yapıların ticari bir amaca hizmet edebilecek şekilde düzenlenmesidir. Nanobilimden yola çıkarak da nanoteknolojinin tanımını yapmak mümkündür. Nanoölçeklerde yapılan bilimsel çalışmalara nanobilimdenmektedir. Uygulamaya dönük nanobilime, nanoteknoloji denmektedir (www.nanoteknolojinedir.com). Nanoteknoloji, "malzemelerin, cihazların ve sistemlerin nano ölçekte şeklini ve ebatlarını kontrol ederek tasarımının, karakterizasyonunun, imalatının ve uygulamasının yapılmasına" verilen isimdir (Abad, 2005: 10). Nanoteknoloji esasen yeni özellikler ve işlevlere sahip malzemeler, cihazlar ve sistemler üretebilmek amacıyla maddenin nano ölçekte planlı ve kontrollü işlenmesi, hassas ölçümü, modellenmesi ve üretimidir. Diğer bir yaygın ifade ise nanometre ölçeğinde en az bir boyutta işlevsel bir düzene sahip malzemelerin, cihazların ve sistemlerin tasarımı, sentezi, karakterizasyonu ve uygulamasıdır (Ramsden, 2011: 3). Amerikan Foresight Enstitüsünün yaptığı tanım ise şu şekildedir: "Nanoteknoloji maddenin yapısının, kullanışlı ve özgün özelliklere sahip yeni malzeme ve cihazlar üretmek için kontrol edilmesine yönelik gelişmekte olan bir grup teknolojiye verilen isimdir."(Ramsden, 2011: 4).

Bir nanometre $(\mathrm{nm}=$ nano metre $=$ metrenin milyarda biri) bir milimetrenin milyonda biri kadar bir uzunluktur ve bir insan saç telinin on binde biri kadar bir kalınlığa tekabül etmektedir. Bu uzunluk terimi atom ve moleküllerin içindeki en küçük mesafeleri tanımlamak için kullanılır. Dört ile altı atom yan yana sıralandığında bu uzunluğa eşit bir uzunluk meydana gelmektedir. Nano derecesindeki parçacıklar (nano parçacıklar) veya polimerler (100nm'den daha küçük) bu teknolojinin yapı taşlarını teşkil etmektedir.

Atomlar bakterilerin 1/10000, bakteriler ise bir sivrisineğin 1/10000 büyüklüğündedirler. Farklı büyüklükleri karşılaştıracak olursak; karıncanın başının genişliği bir milyon nanometre, biyolojik hücrelerin çapı bin nanometre, bir bakterinin içindeki ribozom 25 $\mathrm{nm}$, DNA molekülleri yaklaşık $2 \mathrm{~nm}$, on tane yan yana konmuş hidrojen atomu bir nanometre, atomların çapları nanometrenin onda biridir (Erkoç, 2012: 9). Bu karşılaştırmalara Şekil 1.'de yer alan doğal ve insan yapımı nesnelerden örnek verilmektedir.

Nanoteknoloji, atomlarla oynayan bir teknolojidir. Atom ve molekülleri tek tek maniple ederek istenilen yapının oluşturulması ilkesine dayanır. Atomlar ayrı ayrı işleme tabi tutulur. Yaklaşık 100-1000 atom bir araya gelerek nano ölçeklerde bir nesneyi oluşturmaktadır. Nanoteknoloji de bu bağlamda çok küçük maddelerin teknolojisi olmaktadır (Özdoğan ve diğerleri, 2006: 159). 1 nanometre, hidrojen atomunun çapının sadece 10 katıdır. Ne kadar küçük olduğunu canlandırmak zordur, boyutları giderek küçülen transistorlu radyolar, cep telefonları vb. aygıtlar nanoteknoloji dünyasında yeri olmayan dev yapılardır. Nanoteknoloji kapsamına giren malzemeler için 100 ile 1 nanometre $(\mathrm{nm})$ (1/10 milyon metre ile $1 / 1$ milyar metre) arasındaki herhangi bir büyüklük (uzunluk, genişlik veya kalınlık) ifade edilmektedir. Sadece bir tek boyutu nanometre mertebesinde olsa da, ultra incelikteki kaplamalar da nanoteknoloji kapsamındadır. Örneğin bu durum, seramiklerde (kendi kendini temizleyen seramik taşları), duvar 
renklerinde (kendi kendini temizleyen ev cepheleri) veya camlarda kendini göstermektedir.

\section{Şekil 1: Nanoteknolojik Boyutların Karşılaştırııması}

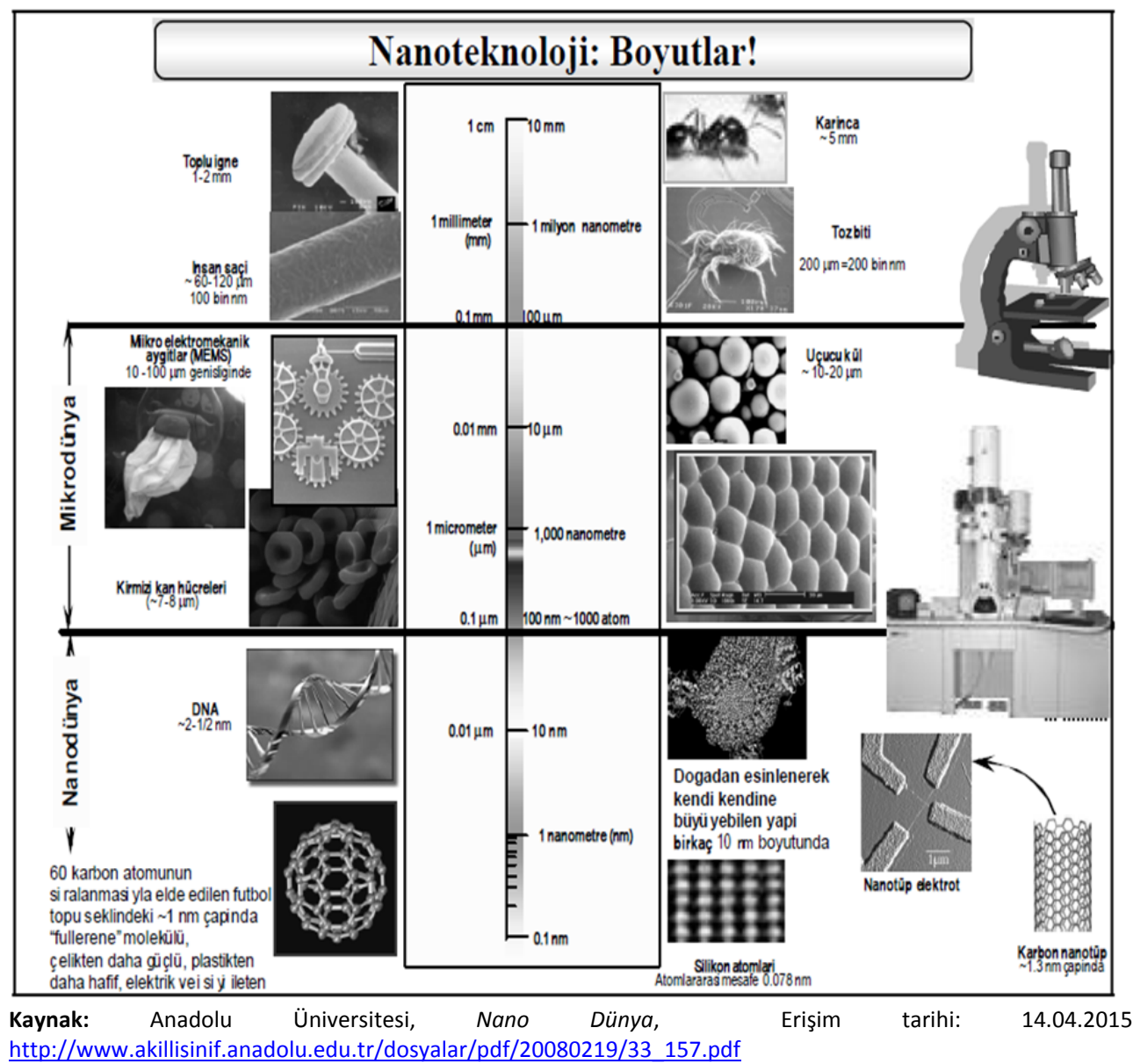

ABD Ulusal Bilim Vakfı, yaklaşık 1-100 nanometre uzunluk ölçeğinde yapılan araştırmalar ve kaydedilen teknolojik gelişmeler; bazı durumlarda kritik uzunluk ölçeği 1 nm'nin altında ya da 100 nm'nin üstünde olabilir şeklinde bir tanımda bulunmuştur (Kut ve Güneşoğlu, 2005: 225).

\section{NANOTEKNOLOJI YATIRIMLARI}

\subsection{Dünyada Nanoteknoloji Yatırımları}

Nanobilim ve nanoteknolojinin çok kuvvetli ve hafif malzemeler, çok küçük bilgisayar parçaları, yeni sensör ve çok hızlı çalışan nanoboyutlu elektronik ve optoelektronik teknolojileri ile çok küçük boyutlu ve aynı zamanda öngörülemeyecek kadar etki gücü yüksek savunma sistemlerini üretebilme yeteneğine sahip olduğuna inanılmaktadır. Geliştirilmeye müsait ve pazarlama potansiyeli yüksek olan bu yeni teknolojinin önemini ve gücünü farkeden ve ileride dünya ekonomisini ve devletlerarası güçler dengesini belirleyici 
olacağına inanan $A B D$, Rusya, $A B$, Japonya ve Çin gibi gelişmiş ve gelişmekte olan ülkeler Nanobilim ve Nanoteknoloji'nin çeşitli alanlarında dev Ar-Ge yatırımları yapmaktadırlar. Öte yandan, bu ülkelerde sayıları süratle artan nanoteknoloji tabanlı çeşitli ölçeklerde şirketler kurulmakta ve devlet destekli üniversite-sanayi işbirliğine büyük önem verilmektedir. Özellikle büyük sanayi kuruluşları nanoteknolojide araştırma ve geliştirmeye yönelik önemli yatırımlar yapmaktadır.

Nanoteknoloji ile eşyaları dönüştürmek, eşyaya yeni nitelikler kazandırmak ve hatta eşyanın temel niteliklerini değiştirmek mümkün olmaktadır. Artık sert olan bir madde yumuşak, yanıcı olan söndürücü, az olan çok, sıvı olan katı, yalıtkan olan ise iletken olabilmektedir. Nanoteknoloji alanındaki çalışmalar, tıptan elektroniğe, enerjiden tarıma hemen her alanda uygulanabilmesi açısından büyük bir değer taşımaktadır. Yapılan araştırmalara göre, 2004 yılında nanoteknoloji ürünlerinin pazar payı 13 Milyar Dolar iken, bu rakamın 2014 yılında 2.5 Trilyon Dolara ulaşacağı tahmin edilmektedir. Nanoteknoloji alanında çalışan müstakil şirketler kadar, farklı sektörlerde faaliyet gösteren büyük firmaların da nanoteknolojidepartmanları oluşturmaya başladığı görülmektedir. Mesela geleceğin dünyasında, nanoteknolojik ürünler neticesinde, özel hayatın güvenliğiyle ilgili ciddi gelişmeler olması beklenmekte ve yine özellikle enerji üretimi ve depolanması, alternatif enerji kaynaklarının oluşması, su arıtma sistemleri gibi alanlarda, nanoteknolojinin çok belirleyici bir alan olacağı gözlemlenmektedir (www.marka.org.tr).

Amerika Birleşik Devletleri'nde 1999 yılında yayınlanan Ulusal Nanoteknoloji Bildirgesi ile ülkenin nanoteknoloji alanındaki öncelikleri belirlenmiş ve bu konuda yapılan Ar-Ge çalışmaları için bütçeler ayrılmıştır. Daha öncede ifade edildiği gibi 2000 yılında nanoteknoloji alanında yapılan Ar-Ge çalışmalarına hükümet tarafından sağlanan destek 420 Milyon Dolar civarında iken 2001 yılı bütçesinde bu alana ayrılan pay yaklaşık 520 Milyon Dolara ulaşmış, 2003 yılı için ise yaklaşık 700 Milyon Dolar olarak belirlenmiştir. Aralık 2003 tarihinde Başkan Bush 2005 yılından başlayarak 4 yıl süreyle nanoteknoloji alanında gerçekleştirilen araştırma ve geliştirme projelerinde kullanılmak üzere 3.7 Milyar Dolar tutarında fon ayrılmasını onaylamıştır.(www.fikir.net).

Asya ülkeleri içinde nanoteknolojiye yatırım yapan ülkelerin başında Japonya gelmektedir. Japonya dünyada ABD'den sonra nanoteknoloji alanında en fazla Ar-Ge harcaması yapan ikinci ülke konumundadır. Nanoteknoloji üzerine yapılmakta olan yatırımın her yıl \%15 ile \%20 oranında artmakta olduğu Japonya'da nanoteknoloji tanımı dünyanın geri kalan ülkelerine oranla çok daha geniş kapsamlıdır. Moleküler seviyede yapılan birçok araştırma (örnek vermek gerekirse, DNA üzerine yapılan araştırmalar) nanoteknoloji tanımı içerisinde yer almaktadır. Ayrıca NEC ve Sumitomo gibi firmalar karbon nanotüpler alanında çalışmalar yürütmekte, araştırmalar gerçekleştirmektedir. Asya ülkeleri arasında Japonya'yı takip eden ülkeler arasında Çin ve Kore öne çıkmaktadır. Çin ülkede yürütülen nanoteknoloji odaklı birçok araştırma ve geliştirme çalışmasını Çin Bilimler Akademisi kanalıyla yürütmektedir. Bu ülkede yürütülen çalışmaların birçoğu yarı iletken üretme teknikleri ve nanoteknoloji tabanlı elektronik cihazlar üzerine yoğunlaşmaktadır. Araştırma merkezlerine ek olarak nanoteknoloji kullanılarak üretilen ürünlerin ticarileşmesine imkân sağlamak amacıyla çalışanbirçok kuruluş bulunmaktadır. Kore nanoteknolojinin mikro elektronik uygulamaları alanında yoğunlaşmıştır. Nanoteknoloji çalışmalarının süründürüldüğü birçok üniversite ve araştırma merkezi olduğu gibi Kore'nin en büyük şirketlerinden biri olan Samsung mikro elektronik uygulamalar ve mikro elektromekanik 
sistemler (MEMS) üzerine araştırmalar yürütmektedir. Tayvan, Singapur, Tayland, Hindistan ve Vietnam nanoteknolojiyi öncelikli alan olarak belirlemiş ve uygun çerçeveyi belirlemek için adımlar atmaktadır (www.fikir.net).

Avrupa Birliği, ABD ve Japonya'yı takip edebilmek için FP 6. Çerçeve programı içinde desteklenmesi gereken öncelikli alanlardan biri olarak belirlediği nanoteknolojiye Ar-Ge faaliyetlerinde kullanılmak üzere yaklaşık olarak 1.30 milyar Euro ayırmış olup bunu FP 7 . Çerçeve programı içinde de yaklaşık iki buçuk katına çıkartmıştır. Özellikle; Almanya, Fransa ve İngiltere'de nanoteknoloji alanındaki Ar-Ge merkezlerinin kurulması ve projelerin geliştirilmesi için yüksek miktarda maddi destek sağlanmaktadır. Birçok $A B$ ülkesinde üniversitelerde nanobilim ve nanoteknoloji konusunda araştırma merkezleri ve enstitüler kurulmuş olup Yüksek lisans ve Doktora programları açılmıştır. Hatta Lisans seviyesinde nanobilim ve nanoteknoloji konusunda eğitim-öğretim yapan bölümler açılmıştır. Almanya, Hollanda, Fransa, İngiltere, Danimarka, İspanya başta olmak üzere tüm Avrupa ülkelerinde pek çok yeni araştırma merkezinin yanı sıra üniversitelerde de nanobilim ve nanoteknoloji faaliyetlerine her yıl milyarlarca dolarlık yatırımlar yapılmaktadır (www.nsne.itu.edu.tr). 7. ÇP'de düşünülen yatırımlar Şekil 2.'de verilmiştir.

Şekil 2: İşbirliği Özel Programı Bütçe Dağııımı

\section{İşbirliği Özel Programı Bütçe Dağılımı (Toplam 32,4 Milyar Avro)}

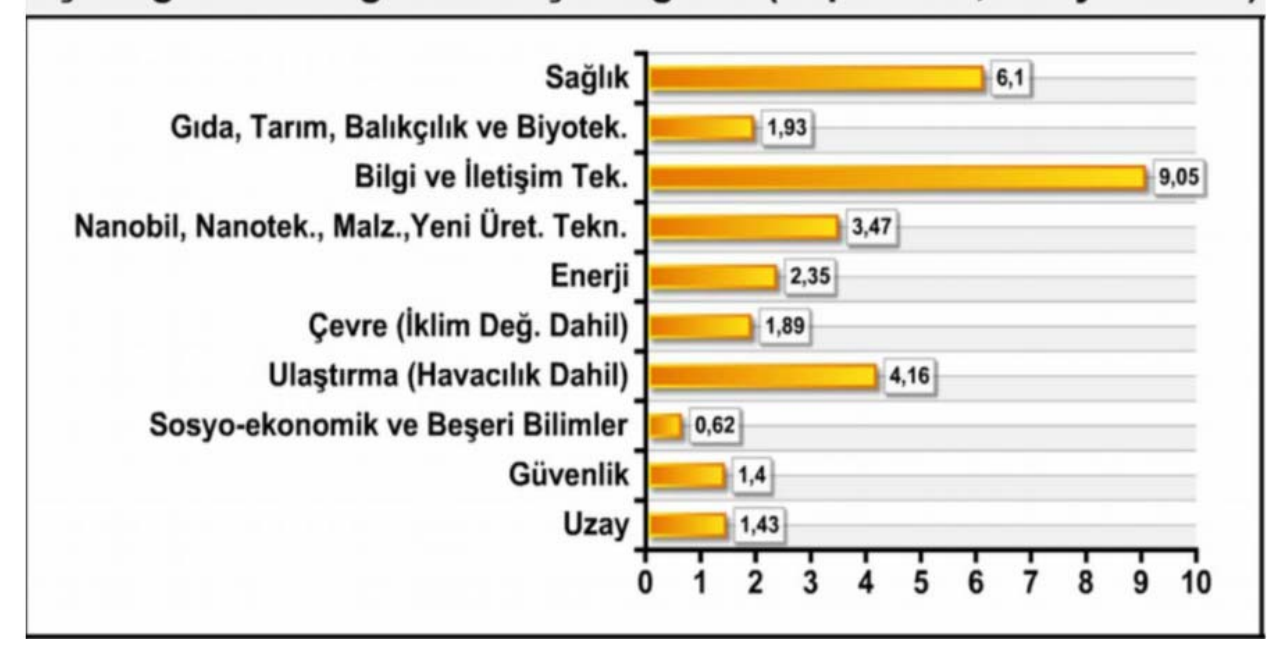

Kaynak:TUBітAK, Ulusal Destekler ve $A B$ Çerçeve Programları'nda KOBi'ler, Erişim tarihi: 08.05.2015,http://www.fp7.org.tr/tubitak_content files/279/Teknopark Bilgi_Gunleri/Bahadir ulusaldesteklerg azi.pdf

2007-2013 yılları arasında uygulanan AB 7.ÇP dâhilinde İşbirliği Özel Programı'na 32,4 Milyar $€$ ayrılması öngörülmüştür. Bu programa bakıldığında nanoteknolojiye ayrılan payın 3,47 Milyar € ile dördüncü sırada yer aldığı ve diğer sektörlerde de yine nanoteknolojik çalışmalar yapıldığı görülmektedir.

\subsection{Türkiye'de Nanoteknoloji Yatırımları}

Ülkemizde nanobilim ve nanoteknoloji hakkındaki gelişmelere bakacak olursak, gelişmiş ülkelerden ciddi bir süre gecikme içinde olduğumuzu görmekteyiz. Dünyadaki gelişmelere 
uymak ve uluslararası standardı yakalamak için, ülkemizde disiplinler arası işbirliğini güçlendirmek gerekmektedir. Ülkemizin gelecekteki menfaatlerini korumak amacıyla nanobilim ve nanoteknolojideki gelişmelerini yakından takip etmek ve tedbirler alabilmek amacıyla bu konuda yatırımlar yapmak bir zorunluluk arz etmektedir.

Türkiye'de nanoteknoloji çalışmaları için yapılan yatırımlar, belli üniversitelerde ve belli akademisyenlerce yapılmaktadır. Bu üniversiteler birinci bölümde ifade edilmiştir. Toplam 19 Araştırma Merkezi, 1000-1200 kadar araştırmacı ve teknik eleman ve 100 civarında nanoteknolojiyi uygulayan küçük-büyük firma bulunmaktadır (Özgüz, 2012: 16). Türkiye’de yer alan bu araştırma merkezlerinin alanlara göre yatırımları Şekil 3.'te verilmiştir.

Şekil 3: Araştırma Merkezi Maliyetlerinin Alanlara Göre Dağılımı

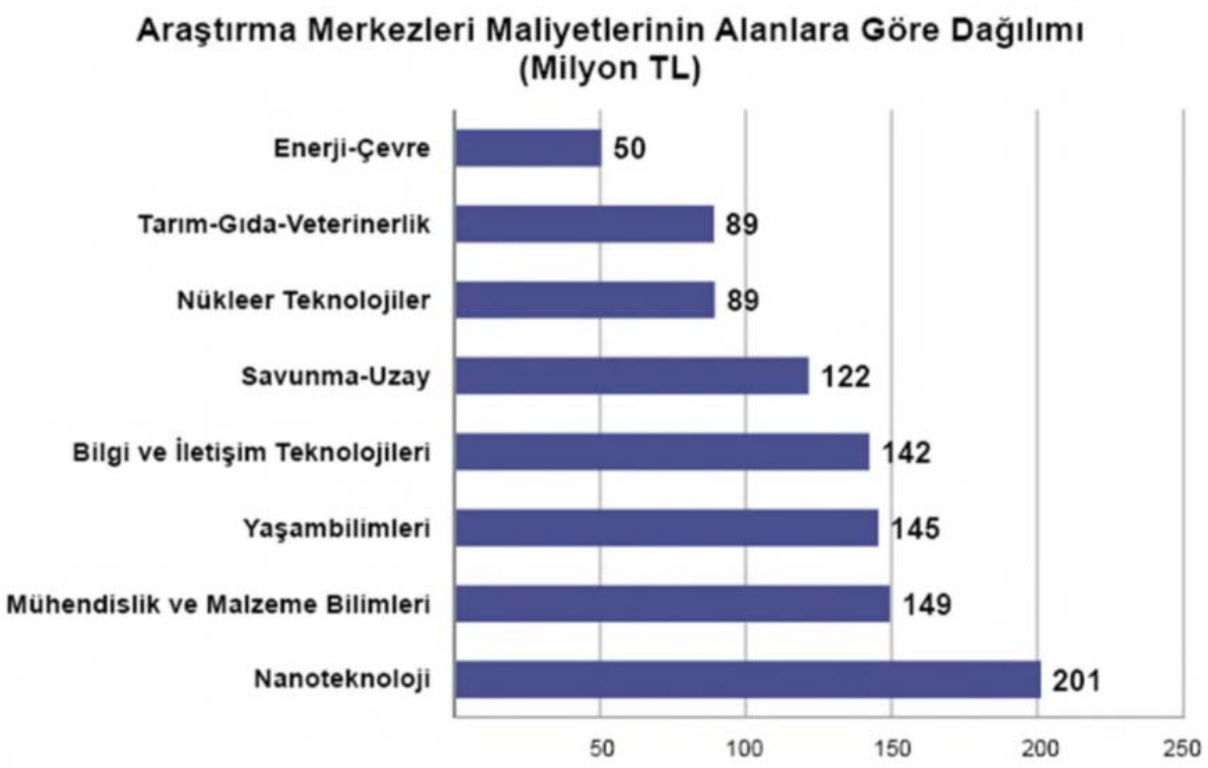

Kaynak: Özgüz, V. (2012). Türkiye'de Nanoteknoloji Araştırma ve Geliştirme, Nanoteknoloji Araştırma ve Uygulama Merkezi Sunumu, İstanbul: Sabancı Üniversitesi Yayınları, s. 16.

Şekilden de anlaşılacağı üzere yapılan çalışmaların büyük çoğunluğunu nanoteknolojik çalışmalar oluşturmaktadır. Yapılan yatırım miktarı 201 Milyon TL olarak belirlenmiştir. Diğer sektörlerde yapılan çalışmaların büyük bir kısmı da yine nanoteknolojiyle alakadardır.

Türkiye'de çeşitli araştırma merkezlerine yapılan yatırımlara bakacak olursak:

Devlet Planlama Teşkilatı (DPT) Müsteşarlığı Bilkent Üniversitesi'nden sunulan proje aracılığı ile ulusal nitelikte bir nanoteknoloji araştırma merkezi kurulması için 11 Milyon TL destek sağlayarak 5 Ekim 2005 yılında UNAM-Ulusal Nanoteknoloji Araştırma Merkezi Projesi'ne başlanılmasını planlamıştır. 2006 yılı ortalarında başlanan ve 1,5 yılda bitirilen UNAM binası yaklaşık $9000 \mathrm{~m}^{2}$ kapalı alan üzerine kurulmuş; içerisinde titreşim ve sıcaklık kontrollü 62 laboratuvar, konferans salonu ve ofisleri barındırmaktadır. $400 \mathrm{~m}^{2}$ temiz oda da 2009 yılı ortalarında faaliyete geçmiştir (http://tr.wikipedia.org). 2013 yılı itibariyle toplam 35 Milyon TL yatırım yapılmıştır (UNAM, 2013: 4). DPT, nanoteknoloji araştırmaları 
için gerekli kaynağı önceleri dağıtmadan, gerekli sayıda araştırmacı ve uzmana sahip tek bir üniversitede toplayarak kısa zamanda sonuç almayı hedeflemiştir. Nanoteknolojideki yönelimler ve gelişmelere uygun olarak araştırma konularına nanobiyoteknoloji, nanomalzeme ve kimya, enerji ve hidrojen ekonomisi, nanotriboloji, yüzey kaplama, katalizör tasarımı gibi çok güncel konular da eklenmiştir. Ayrıca, disiplinler arası çalışmaya olanak vermek ve nanoteknoloji uzmanı yetiştirmek amacıyla "Malzeme Bilimi ve Nanoteknoloji" yüksek lisans ve doktora programı açılmıştır. UNAM'a 2007'de TÜSIAD, 2008'de TÖV ve 2009'da TÜBITAK tarafından bilim ve teknoloji ödülleri verilmiştir (http://tr.wikipedia.org).

Gebze Yüksek Teknoloji Enstitüsü (GYTE) Nanoteknoloji Merkezi kuruluşunu DPT katkılarıyla 2003 yılında gerçekleştirmiştir. Şuana kadar 3 Milyon Dolar harcanan merkezde,güneşenerjisi,hidrojen teknolojileri ve manyetik malzemelere yönelik projeler yapılmaktadır. Merkezin alt yapısında X-ışınları FotoelektronSpektroskobisi (XPS),(MHR) ve Atomik Kuvvet Mikroskobu (AFM) gibi nanoteknoloji alanına yönelik bilimsel çalışmalarda kullanılan cihazlar mevcuttur. Merkezde ileride nanoteknoloji alanında çalışmalar yapabilecek elemanların yurtiçi ve yurtdışı projelerde çalıştırılarak yetiştirilmesi, uluslararası projeler yapılarak ülkemizin nanoteknoloji sürecinde donanımlı kılınması hedeflenmektedir (www.gyte.edu.tr).

Sabancı Üniversitesi Nanoteknoloji Araştırma ve Uygulama Merkezi (SUNUM), T.C. Kalkınma Bakanlığı ve Sabancı Vakfı'nın katkıları ile yaklaşık 60 Milyon TL yatırımla kurulmuştur. SUNUM'da $7400 \mathrm{~m}^{2 \prime}$ lik özgün ve öncü tasarımlı bir merkez binası içinde, 850 $\mathrm{m}^{2}$ oda, toplam 1,500 $\mathrm{m}^{2}$ alana yayılmış laboratuvarlar ve $2400 \mathrm{~m}^{2 \prime}$ lik ofis ve ortak kullanım alanı bulunmaktadır. SUNUM'da ileri malzemeler, nanobiyoteknoloji, nanotıp, nanoelektronik, nanooptik, mikro-nano-akışkanlar, mikro-nano-elektromekanik sistemler ve yenilenebilir enerji sistemleri alanlarında disiplinlerarası araştırmalar yapılmasını sağlayan imkânlar bulunmaktadır (http://nano.sabanciuniv.edu).

\section{NANOTEKNOLOJI YATIRIMLARININ MALIYETLERE ETKISI}

1990 'I yıllarda gelişmeye başlayan ve 2000 'li yıllarda dünya geneline yayılan nanoteknoloji artık elde edilmesi gereken, araştırılan ve ülkelere güç kazandıran bir olgu haline gelmiştir. İşletmeler tarafından çok fazla Ar-Ge yatırımı yapılmakta, devletler tarafından teşvikler verilmekte ve araştırılması için milyarlarca dolarlık kaynak ayrılmaktadır. Bunun nedeni ise geleceğin teknolojisini elde etme amacıdır. Çünkü bu teknolojinin sağladığı katma değer oldukça fazladır. Aşağıda belirtilen durum bunu net bir şekilde ortaya koymaktadır:

Örneğin: 1 kg ürün fiyatına göre (http://www.bursa smmmo.org.tr )

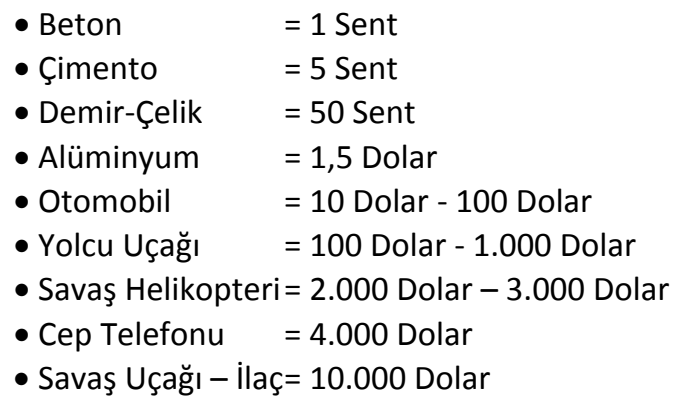


- Uydu

- Mikro ve Nano Yonga ${ }^{1}$

$$
=100.000 \text { Dolar }
$$$$
=4 \text { Milyon Dolar }
$$

Nanoteknoloji, sadece bir alanı ilgilendirmeyip disiplinler arası bir olguyu teşkil etmektedir. Mesela; nanoteknolojik bir çalışma yapılırken bu çalışmayı yapan fizik, kimya, elektrik, elektronik mühendislerine ihtiyaç olduğu gibi yatırımların analizinde ve projelendirilmesinde işletmeciye, hastalıklara ve insan vücudundaki ihtiyaçlara göre belirlenmesinde tıpçıya, dokuma sanayinde tekstilciye, çelik ve çimento yapımında ustaya ve tüm bunları bir araya getirebilecek girişimciye de ihtiyaç duyulmaktadır. Ayrıca sadece teknoloji sektörünü değil sağlıktan enerjiye, imalattan tarıma, dokumadan petrole tüm sektörleri içine alan geleceğin teknolojisi konumundadır.

Nanoteknoloji sayesinde tasarruflar artarken maliyetler düşmekte, enerji verimliliği sağlanarak zaman etkili ve verimli kullanılmaktadır. Daha kaliteli ürünler üretilerek insanlığın refah seviyesi yükseltilirken bu tür ürünler daha çok tercih edilerek işletmelerin satış hacmi artmaktadır. Nanoteknoloji, bilim ve iş dünyası tarafından öncelikli alan olarak ele alınmış, tüm dikkatler bu olguya çevrilmiştir. Sadece Türkiye'de yapılan yatırımlar sonucu ortaya çıkan bir takım nanoteknolojik ürünler ve bunlarla ilgili yapılan yorumlar aşağıda sıralanmıştır:

> Bilkent Üniversitesi Mühendislik Fakültesi Elektrik-Elektronik Mühendisliği Bölümü Öğretim Üyesi ve Bilkent Üniversitesi Uzay Teknoloji Araştırma Merkezi (BILUZAY) Başkanı Prof. Dr. Ekmel Özbay'a göre; Uzayda yüksek oranda radyasyon bulunması nedeniyle uzay ortamında bulunan elektronik devrelerin çok kısa sürede bozulduğu, bu nedenle uyduların çok kalın alüminyum tabakalarla korunduğunu ve radyasyonu soğurma görevini yürüten kalın alüminyum kaplamaların uydu maliyetlerini de ciddi olarak arttırdığını ifade eden Özbay, uzayda bulunan radyasyona dayanıklı yeni malzemelerin geliştirilmesi ile uyduların daha ucuz ve daha uzun ömürlü olacağını belirtmiştir. Geliştirdikleri malzemenin galyum nitrit tabanlı olduğunu aktaran Özbay, bu tür nanoteknolojik malzemelerle uyduların hafif olarak tasarlanmasının mümkün olacağını, malzemenin uzaya tam uyumunun da mümkün olduğunu belirtmiştir. Özbay: "Geliştirdiğimiz malzeme, uzayda mevcut kullanılan malzemelere oranla radyasyona karşı 100 kat daha dayanıklılık gösteriyor. Ayrıca bu malzemeyi kullandığımız nanotransistörlerin yer aldığı elektronik devreler çok daha yüksek hızlarda uzay ortamında çalışabiliyor. Bu nedenlerle uydu sistemlerinin daha ucuza üretimi de mümkün olabiliyor. Uydunun en kritik kompenentleri arasında bulunan verici antenlerinde de bu malzemeyi kullanıyoruz. Yani çalışmamızla nanoteknolojiyi uzaya taşıdık diyebiliriz."(www.radikal.com.tr) diyerek, üretilen nanoteknolojik ürünün hem maliyetlere olumlu etkisi, hem de kaliteyi oldukça fazla arttırdığı ifade edilmiştir. Bu galyum nitritin sadece uzayda kullanılan malzemelere değil diğer malzemelerde de kullanılmasının maliyetlere ne derece olumlu katkı sağlayacağı apaçık bir gerçektir.

\footnotetext{
${ }^{1}$ Yonga: Milimetrik yüzeyler üzerinde on binlerce devre elemanından oluşan ve son derece karmaşık elektronik devrelerin yerleştirildiği, genellikle silikon benzeri yarı iletken malzeme ya da çip olarak tanımlanmaktadır.
} 
> Merkezi Kırklareli'de bulunan NNT Nanoteknoloji Bor Ar-Ge A.Ş. araştırmacıları, uzun yıllar üzerinde çalıştığı Ar-Ge projelerinin sonunda, nanoteknoloji ile boru kullanarak "beş milimetre boyutunda alüminyum kurşungeçirmez zırh" üretmiştir. NNT Nanoteknoloji Bor A.Ş. İcra Kurulu Başkanı Cafer Akın, AA muhabirine yaptığı açıklamada, kurşungeçirmez alüminyum zırhın, tüm savunma sanayisine ait projelerde, özel sektörlerde, zırhlı olması gereken çelik yelekler dâhil olmak üzere yüzlerce alanda kullanılabileceğini ifade etmiştir. Bu nanoteknolojik ürünü Cafer Akın şöyle ifade etmiştir: "Normal zırhlı araçların, ağırlık olarak performans düşüklüğ̈̈, ayrıca yüksek gider maliyetleri, araç lastiklerinin daha çabuk yıpranması, araçların performansının ve hareket kabiliyetinin düşmesi, yüksek yakıt harcaması gibi durumlarıyla kıyaslandığında, kurşungeçirmez alüminyumun kullanılması, çok büyük ekonomik kazanç ve daha güvenli sistem getirecektir. Dünya devleri de bu gerçeğin farkında olduğundan ürettiğimiz bu teknolojiden yararlanmak için hareket ediyor. Biz bu durumdan ülkemiz adına gurur duyuyoruz." Akın, şöyle devam etmiştir: "Çelikten üç kere daha az yoğunlukta ve daha fazla sertlik kazandırılmış alüminyum alaşımlar, kullanıldıkları alana göre, makinelerin boyut ve ağırlıklarının azalması, az enerji harcamaları nedeniyle ekonomik oluşları ve birçok değişik konuda çelikten daha çok mukavemet sağlar. Geliştirdiğimiz METABORON isimli 5 milimetrelik levhalardan makam araçları, korumaya tabi özel ve tüzel kişiler, askeri personel, savunma sanayi ve zırhlı araç kullanabilecek birimlere özel sipariş gerekmeden, ülkemizde üretilen zırhlı araç sektöründe seri üretim imkânı sağlayacağını düşünüyoruz." şeklinde konuşmuştur. Ayrıca Cafer Akın, firmalarının nanoteknoloji ve bor kullanarak fiziksel nanoyağlayıcı olan Bor Power teknolojisini, alternatif tıp alanında birçok dermatoloji ve kardiyoloji başta olmak üzere sağlık alanında kanserli tümör tedavilerinde kullanılacak özel projelerin yanında elektronik ve bilişim alanında da projeler geliştirdiğini sözlerine eklemiştir (www.nnt.com.tr). Dünyada sadece 8 ülkede bor rezervi bulunmakla birlikte önemli bor yatakları Türkiye, $A B D$ ve Rusya'da yer almaktadır. En önemli bor yataklarının yer aldığı Türkiye toplam 3 milyar ton rezerv miktarı ile Dünya toplam bor rezervi sıralamasında \%73'lük pay ile ilk sırada yer almaktadır (www.enerji.gov.tr). Bu durumun bir fırsata çevrilmesi hem ülkemiz açısından hem de işletmelerimiz açısından oldukça önemlidir.

$>$ Kordsa Global Endüstriyel İplik ve Kord Bezi Sananayi ve Ticaret A.Ş. tarafından üretilen bir nanoteknolojik ürün olan "Monolyx"un proje özeti şu şekilde ifade edilmiştir: "Etkisini azaltan ve dolayısıyla lastiklerin yuvarlanma direncini ve yüzey sürtünmesini düşüren lastik tasarımlarının geliştirilmesi sektörde öncelikli ve gerekli hale gelmiştir. Özet kullanımlı bazı lastik tiplerinde birkaç kat çelik kuşak kullanılmaktadır. Çelik kuşağın en az bir katını monofilaman sentetik elyaf ile değiştirmek, lastiğin hafiflemesine ve buna bağlı olarak yuvarlanma direncinin düşmesine ve yakıt tasarrufu sağlanmasına neden olmaktadır. Monolyx, çelik kord yerine geçebilecek çok katlı monofilamankord ürünü, lastik üreticilerinin uzun ömür, düşük benzin tüketimi, düşük lastik ağırlığı ve emisyonların azaltılması gibi önceliklerinin birçoğuna çözüm sunmaktadır." (http://teknoloji.org.tr ). Bu durumda yine üretilen ürünün hem maliyetlerdeki düşüşe hem de kalitedeki artışa neden olduğunu göstermektedir. 
$>$ İpekiş Genel Müdürü Aşkın Kandil, insanların gelecek dönemde sadece kalite ve görünümle yetinmeyeceklerini belirtmiş, kalite ve görünümün yanında yaşam kalitesini artıran, kullanım kolaylığı ve konfor sağlayacak inovatif, fonksiyonel ürünlerin tercih sebebi olacağını dile getirmiştir. Bu doğrultuda nanoteknoloji ve mikro kapsül teknolojilerini ve avantajlarını kullanarak "Kumaşın 7 Harikası" konseptiyle akıllı kumaş koleksiyonu oluşturduklarını söyleyen Kandil, konseptle ilgili olarak "Her biri farklı fonksiyonlar kazandırımış akıllı kumaş koleksiyonumuzda maksimum hareket kabiliyeti ve dayanıklılık sağlayan PureWoolstretch, su ve leke tutmayan BionicFinish, antibakteriyelSilverplus, zayıflamaya yardımcı Slimming, gün boyu hoş koku yayan kadın ve erkeklere özel parfüm kokulu Bioperfume, polen itici Zeropolen, koyu renklerde yakıcı güneşe rağmen serin tutan, UV etkisini azaltan Cooldark ve stresi azaltıp yorgunluk gideren Zerostress olmak üzere toplam sekiz kumaş bulunuyor. Önümüzdeki dönemde de yenilikçi kumaşlarımızla tüketicilerin farklı ihtiyaçlarına cevap vermeye devam edeceğiz" ifadesini kullanmıştır (www.textotex.com). Bu da göstermektedir ki üretilen ürünler toplumun refah seviyesini arttırmakta ve işletmeyi rakiplerine karşı üstün tutmaktadır.

Bu durumlarda göstermektedir ki gelişen bir Türkiye'de üretilen nanoteknolojik ürünler sayesinde ürünlerin maliyetleri düşmekte, mukavemetleri ve kaliteleri artmakta, enerji ve zaman tasarrufu sağlanmakta, ürünlerin özellikleri arttırılarak hem ürünlerin yaşam süreleri uzatılmakta hem de insanlığın refah seviyesi arttırılmaktadır. İşletmelerin bu olguya oldukça fazla önem vermesi yatırımların bu noktaya odaklanması gerekmektedir.

\subsection{Yöntem}

Bu bölümde yukarıda ifade edilen durumu önceden hisseden ve yatırımlarını buna yönelten bazı işletmelerin yapmış oldukları yatırımların işletmenin maliyetlerine etkisi incelenmektedir. Ulusal pazarda yer alan ve nanoteknoloji yatırımları yapan beş imalat işletmesi (AKIN TEKSTIL A.Ş., AKSA AKRILIK KIMYA SANAYii A.Ş., ARÇELIK A.Ş., DYO BOYA FABRIKALARI SANAYI VE TICARET A.Ş. ve VESTEL ELEKTRONIK SANAYI VE TICARET A.Ş.) ele alınmakta ve yapılan yatırımların finansal açıdan etkileri analiz edilmektedir. Bu yatırımlarda oluşan değişim ile işletmelerin satış hacmi ve maliyetler arasındaki ilişki korelasyon analizine, yapılan yatııımların satışlara etkisi regresyon analizine tabi tutulmuştur. Daha sonra Ar-Ge Yatııımları ve Satışların Maliyetinin Satışlara oranı Dikey Analize tabi tutulmuş elde edilen sonuçlara Trend Analizi uygulanmıştır. Çalışmada kullanılan veriler için enflasyon düzeltmesinden sonraki yıl olan 2005 yılı baz yıl kabul edilmiş ve 2014 yılıı da içine alan son on yıl ele alınmıştır. Veriler Kamuyu Aydınlatma Platformu ve Borsa istanbul'dan elde edilmiştir. Analizler yapılırken nanoteknoloji yatııımlarını temsil eden Ar-Ge Yatııımları (ARGEYAT), işletmenin satış hacmini ifade eden Net Satışlar (NETSAT) ve Satışların Maliyeti (SATMALi) olarak ifade edilmiştir.

\subsection{Bulgular}

Çalışmada ele alınan şirketler ve ürettikleri nanoteknolojik ürünler aşağıda sıralanmış ve çeşitli finansal ve ekonometrik analizlere tabi tutulmuştur.

AKIN TEKSTiL A.Ş.: Akın Tekstil A.Ş. tam entegre tesislerinde yurtiçi ve yurtdışı piyasalar için imal ettiği teknik kumaşlar ile Türkiye'nin önde gelen teknik tekstil üreticileri arasında 
yer almaktadır. Üretimini 120.000 metrekarelik kapalı alanda, yaklaşı 1600 mavi ve beyaz yakalı çalışanıyla aylık 2 milyon metre olarak gerçekleştirmektedir. Şirket "co-generation" sistemi ile sarf ettiği elektriği kendisi üretmektedir. Teknik iplikler ve kumaşlar ISO 9001:2000 VE OEKOTEX 100 kalite standartlarına uygun olarak imal edilmekte, kumaşlar uluslararası alevalmazlık standartlarına uygun şekilde test edilerek sertifikalandırılmaktadır (www.akintekstil.com.tr). İşletmede nanoteknolojik özelliklere sahip özel elyaflar kullanılarak endüstriyel ve askeri amaçlı uygulamalar için alevalmaz, yanmaz, güç tutuşur, teknik iplikler üretilmektedir. Şirket son olarak ultra viole ışınlarını geçirmeyen ve geri yansıtan, soğuk ve sıcağa karşı vücut ısısını en uygun seviyelerde tutan, özel olarak hazırlanmış kumaşlarını C-Addition markası ile satışa sunmuştur.

\section{Üretilen Nanoteknolojik Ürünler Aşağıda Sıralanmıştır.}

$>$ Alevalmaz (Yanmaz) İplikler

$>$ Alevalmaz (Yanmaz) iş Elbisesi Kumaşları

Alevalmaz Gemi Kumaşları

> Alevalmaz Uçak Döşemelik Kumaşlar

$>$ Leke Tutmaz ve Antibakteriyel Otel-Ofis Kumaşları

> Alevalmaz (Yanmaz) Apre Fason İşlemleri

AKSA AKRiLiK KimYA SANAYii A.Ş.: İşletme kompozit bir malzemeden üretilen ve nanoteknolojik açıdan son derece önemli olan "Karbon Elyaf" üretimi yapmaktadır. Karbon elyaf, çeliğe göre 3 kat dayanıklı ve 5 kat daha hafiftir. Çürümemekte, paslanmamakta, kırımamakta ve esnememektedir. Saç telinin onda biri kalınlığında ve bal peteğine benzeyen bir yapıda üretilmektedir. Uzay ve havacıllı sektöründe, kara ve deniz taşımacılığında, endüstiyel malzemelerde, bina alt yapı güçlendirmelerinde, rüzgâr santrallerinde ve spor malzemelerinin yapımında kullanılmaktadır. Çok hafif olduğu için taşıma ve kullanım maliyetlerinin düşük olmasına ve performansın artmasına yardımcı olmaktadır. Bu yüzden Formula 1 yarı̧̧ araçlarının iskelet sistemlerinde karbon elyaf tercih edilmektedir. Birçok ünlü otomobil firmaları iddialı modellerinde bu nanoteknolojik ürünü kullanmaya başlamışlardır (www.paraborsa.net).

ARÇELiK A.Ş.: Arçelik A.Ş.'nin 1990'dan bu yana hız kesmeden sürdürdüğü Ar-Ge ve teknoloji yatırımları, uluslararası pazarlarda da sektörünün önde gelen şirketlerinden biri olmasını sağlamıştır. Arçelik A.Ş., üstün teknolojiye sahip, yüksek kaliteli ve yenilikçi ürünleriyle, Ar-Ge alanında dünyanın önde gelen oyuncularından biridir ve 100 'den fazla ülkede kendi tasarladığı ve ürettiği ürünleri kendi markaları ile pazarlamaktadır. Yenilikçilik alanında yıllardır devam eden çalışmalar ve alınan sonuçlar meyvelerini vermiş ve 2013 yılında da Arçelik A.Ş. TiM'in Türkiye İnovasyon Haftası'nda "inovasyon Liderliği” ödülüne layık görülmüştür. Arçelik A.Ş., Türkiye'nin, kendi teknolojisini üreten ve kendi teknolojisini yaptığı patent başvurularıyla koruyan bir şirketidir. Türkiye Patent Enstitüsü tarafından düzenlenen listede "Patent Şampiyonluğu"nu uzun yıllardır açık ara sürdürmeye devam etmektedir. Türkiye'de Ar-Ge kültürünün gelişmesinde etkin bir role sahip olan Arçelik A.Ş., Ar-Ge faaliyetlerini yerel ve global ölçekte başarıyla sürdürmektedir.

1974 yılında Türkiye'nin ilk otomatik çamaşır makinesi üretilmiş, 1975'te özel sektörün ilk Araştırma ve Geliştirme (Ar-Ge) bölümü açılmıştır. Türkiye'nin ilk çamaşır kurutma makinesi 2005 yılında Arçelik A.ş. tarafından üretilmiş ve nanoteknolojik araştırmalar sonucu 2007 yılında ilk "parmak izi bırakmayan" ankastre ürün gamı geliştirilmiştir 
(www.koc.com.tr). Dünya markası olma hedefinin Ar-Ge ve yenilik yoluyla kazanılacağının bilinci ile Arçelik A.Ş., yenilikçi yaklaşımla geliştirdiği ve kendine özgü dokunuşuyla farklılaştırdığı nanoteknolojik ürünleri ve üretim süreçleri ile tüketicilerin değişen ve artan beklentilerinin ötesine geçmeyi başarmaktadır. Bu sayede, tüketici elektroniği sektöründe de ulusal ve uluslararası düzeyde rekabet edebilir yapısını sürdürmektedir.

DYO BOYA FABRIKALARI SANAYi VE TiCARET A.Ş.:Teknolojinin ulaşabildiği en yüksek noktada ürünler sunmayı prensip edinmiş olan Yaşar Boya Grubu dünya teknolojisinde gelinen en son noktayı nanoteknolojiyi boyaya uygulamıştı. DYO, 55 yılı aşan tecrübesi ile titiz ve uzun Ar-Ge çalışmaları sonucunda 21. yüzyılın teknoloji devrimi simgesi olacak nanoteknoloji ile üretilmiş boyaları, Türkiye'de ilk kez 2005 yılında Türk halkının kullanımına sunmuştur. DYO'nunnanoteknoloji kullanarak geliştirdiği bu ürünler ileri teknolojinin avantajlarını taşımasının yanında, boyada daha düne kadar hayal olan işlevlerin gerçekleşebilmesini mümkün kılmaktadır. "Akıllı boyalar" olarak da bilinen nanoteknolojik ürünler koruyucu ve dekoratif olmanın yanısırafotokatalitik temizleme özelliği sayesinde ışıkla kendi kendini temizleyen ve ortam havasını temizlemeye katkıda bulunan, antimikrobiyel ve yangın geciktirici gibi özellikleriyle boya pazarındaki rekabette DYO'nun haklı gururu olmuştur.

Ayrıca nanoteknoloji kullanılarak tasarlanan UV kürlenmeli, yüksek çizilme direncine sahip vernikler, çift komponentli fırça ve rulo ile uygulanabilen vernikler, yangın geciktirici vernikler de DYO tarafından üretilerek Türk tüketicisinin kullanımına sunulmuştur. DYO, nanoteknolojik ürünlerde dünya ölçeğinde önde giden birkaç firmadan birisidir. DYO'nunnanoteknoloji ile ürettiği ürünler için 2005 yılında Türk Patent Enstitüsüne yaptığı başvuru, 2007 yılı sonunda onaylanarak başarıyla sonuçlanmıştır.DYO, nano ürünlerinin sağladığı başarının uluslararası alanda daha da pekişmesi amacıyla Avrupa Patent Ofisine de başvurmuştur. Yapılan ilk incelemede DYO'nun gerekli kriterleri sağladığına ilişkin ön rapor hazırlanmıştır. Böylece, Avrupa Patent Ofisi (EPO), DYO'nunnano ürünlerine patent belgesi verilmesine karar vermiştir. DYO, fotokatalitik boyalarda solgel yöntemiyle Nano Patent alma başarııını gösteren ilk ve tek Türk şirketi olmuştur (www.birbilenesorun.com.tr).

VESTEL ELEKTRONiK SANAYi VE TiCARET A.Ş.: Kullanıcıların ihtiyaçlarına bağlı olarak ürünlerin yaşam eğrileri kısalmaktadır. Tüketici taleplerine bağlı gelişen pazar şartlarında Ar-Ge çalışmaları giderek önem kazanmıştır. Vestel, bu dönemde bir taraftan teknolojik gelişme ve kurumsallaşma sürecine büyük önem verirken, diğer taraftan da dünya pazarında etkin rol almaktadır.

Vestel, LCD TV ve beyaz eşyada yüksek kapasitesi ve altyapısıyla Avrupa pazarındaki üstün OEM ve ODM konumunu ileriye taşımaya kararlıdır. Vestel, belirlediği coğrafi genişleme alanında üretim ve markalaşma stratejisini sürdürmektedir. Grup, Rusya'da başarıyla gerçekleştirilen ilk aşamanın ardından, ürünlerini BDT Ülkeleri (Azerbaycan, Gürcistan, Ermenistan, Türkmenistan, Özbekistan, Kırgızistan, Kazakistan), Orta Doğu, Kuzey Afrika (Libya, Fas), Kıbrıs ve Güney Asya gibi gelişmekte olan pazarlarda satarak Vestel markası ile büyümeyi öngörmektedir.

Vestel, LCD alanındaki Ar-Ge çalışmalarını görüntü iyileştirmeye dönük yazılım projeleri üzerinde yoğunlaştırmaktadır. 2007'de piyasaya sunulan Pixellence LCD TV'ler büyük yankı uyandırmış, bu alandaki çalışmalar hız kazanmıştır. Bugün Pixellence teknolojisi, 40’a varan 
patent sayısı ve gelişen türevleriyle Vestel'in görüntü iyileştirme yazılımları alanındaki başarılarını uluslararası arenada da tescil ettirmektedir. LCD sektöründeki incelik trendini takip eden Vestel, 2008 yılında Türkiye'de bir yerli üretici tarafından üretilen en ince LCD'ye imza atmıştır. (www.zorlu.com.tr).

Vestel için "convergence" ürünleri giderek önem kazanmaktadır. Tüketici elektroniğinde esnek üretim modelinden ve telekomünikasyonda gömülü yazılımdan kaynaklanan üstünlüğünü, bilgi teknolojilerinde dizüstü bilgisayar üretimiyle kazandığı güçle birleştiren Vestel, "convergence" ürün alanındaki hedef konumuna doğru emin adımlarla ilerlemektedir.

Yeşil Konsept (GreenConcept) de Vestel'in gelişim haritasında öne çıkan bir diğer konudur. Çevreci ürünler özellikle Avrupa pazarında ağırlı̆ı̆ı artırırken, Vestel 2 yıldır sürdürdüğü zararlı alaşım içermeyen, $A B$ mevzuatına uygun üretimin yanı sıra, enerji tasarrufu sağlayan ürünlerde de büyük ilerleme kaydetmektedir (www.zorlu.com.tr).

Doğaya zarar vermeyen, kaynakları verimli kullanan Eco TV modellerin geliştirilmesi, gerek içerdiği bileşenler ile gerekse de enerji tasarrufu ile yeni Ar-Ge çalışmalarının önünü açmıştır. Ürünlerin mekanik ve elektronik parçalarında kullanılan kimyasal maddelerdeki sınırlamaların ardından normal çalışma modunda \%70'lere varan enerji tasarrufu sağlayan ürünlerin üretilebilmesi için elektronik ve ekran teknolojilerinde önemli değişimler yaşanmaktadır (www.zorlu.com.tr).

Yukarıda belirtilen ve nanoteknoloji yatırımları konusunda ön planda yer alan şirketlerin yapmış olduğu yatırımları temsil eden Ar-Ge yatırımlarının Net Satışlar ve Satışların Maliyeti ile olan ilişkisi Korelasyon analizine tabi tutulmuş ve elde edilen sonuçlar Tablo 1 'de gösterilmiştir.

Tablo 1: Şirketlerin Yapmış Oldukları Ar-Ge Yatırımları ile Net Satışlar ve Satışların Maliyeti Arasındaki Korelasyon Analizi

\begin{tabular}{|c|c|c|c|c|}
\hline & & ARGEYAT & NETSAT & SATMALI \\
\hline \multirow{3}{*}{ AKIN TEKSTIL A.Ş. } & ARGEYAT & 1 & & \\
\hline & NETSAT & -0.716416 & 1 & \\
\hline & SATMALI & -0.595578 & 0.929623 & 1 \\
\hline \multirow{3}{*}{ AKSA AKRILIK KIMYA SANAYIi A.Ş. } & ARGEYAT & \begin{tabular}{l|l}
1 \\
\end{tabular} & & \\
\hline & NETSAT & 0.262574 & 1 & \\
\hline & SATMALI & 0.164023 & 0.987360 & 1 \\
\hline \multirow{3}{*}{ ARÇELIK A.Ş. } & ARGEYAT & 1 & & \\
\hline & NETSAT & 0.844131 & 1 & \\
\hline & SATMALI & 0.836486 & 0.994190 & 1 \\
\hline \multirow{3}{*}{$\begin{array}{l}\text { DYO BOYA FABRIKALARI SANAYI } \\
\text { VE TICARET A.Ş. }\end{array}$} & ARGEYAT & 1 & & \\
\hline & NETSAT & 0.996462 & 1 & \\
\hline & SATMALI & 0.989203 & 0.993914 & 1 \\
\hline \multirow{3}{*}{$\begin{array}{l}\text { VESTEL ELEKTRONIK SANAYI VE } \\
\text { TICARET A.Ş. }\end{array}$} & ARGEYAT & 1 & & \\
\hline & NETSAT & 0.817882 & 1 & \\
\hline & SATMALI & 0.757742 & 0.984930 & 1 \\
\hline
\end{tabular}


Yapılan analiz sonuçları değerlendirildiğinde şirketler arasında farklılıkların olduğu göze çarpmaktadır. AKIN Tekstilde yapılan yatırımlarla Net Satışlar ve Satışların Maliyeti arasında Negatif bir ilişkiye rastlanırken, diğer şirketlerin tamamında pozitif bir ilişkinin mevcut olduğu görülmektedir. Arçelik A.Ş., DYO Boya Fabrikaları Sanayi ve Ticaret A.Ş. ve Vestel Elektronik ve Ticaret A.Ş. analiz sonuçlarına bakıldığında çok yüksek oranda bir ilişkinin mevcut olduğu özellikle Satışlar ile yapılan yatııımlar arasında \%80'leri geçen bir oranda ilişkinin olduğu tespit edilmiştir.

Ayrıca işletmenin satış hacmini gösteren Net Satışlarla yapılan yatırımlar arasında bir etkileşimin olup olmadı̆̆ı, yapılan yatırımların satışları etkileyip etkilemediğinin tespit edilmesi amacıyla regresyon analizi uygulanmış ve her işletme açısından elde edilen sonuçlar Tablo 2.'de sıralanmıştır.

Tablo 2: Ar-Ge Yatırımları ile Net Satışlar Arasındaki Regresyon Analizi

\begin{tabular}{|c|c|c|c|c|}
\hline \multicolumn{5}{|c|}{ (AKIN TEKSTIL A.Ş. } \\
\hline & Katsayılar & Standart Hata & $\mathrm{t}$ istatistiği & Olasılık \\
\hline $\mathrm{C}$ & $2.54 \mathrm{E}+08$ & 37393091 & 6.792750 & 0.0001 \\
\hline \multirow[t]{3}{*}{ ARGEYAT } & -35.73161 & 12.30252 & -2.904414 & 0.0198 \\
\hline & $\mathrm{R}^{2}$ & 0.513252 & F-ìstatistiği & 8.435618 \\
\hline & Durbin-Watson & 1.524557 & F-Olasılık & 0.019758 \\
\hline \multicolumn{5}{|c|}{ AKSA AKRILIK KIMYA SANAYii A.Ş. } \\
\hline & Katsayılar & Standart Hata & t istatistiği & Olasılık \\
\hline $\mathrm{C}$ & $1.20 \mathrm{E}+09$ & $2.61 \mathrm{E}+08$ & 4.600356 & 0.0018 \\
\hline \multirow[t]{3}{*}{ ARGEYAT } & 17.57807 & 22.83818 & 0.769679 & 0.4636 \\
\hline & $\mathrm{R}^{2}$ & 0.068945 & F-İstatistiği & 0.592406 \\
\hline & Durbin-Watson & 0.549502 & F-Olasılık & 0.463608 \\
\hline \multicolumn{5}{|c|}{ ARÇELIK A.Ş. } \\
\hline & Katsayılar & Standart Hata & $\mathrm{t}$ istatistiği & Olasılık \\
\hline $\mathrm{C}$ & $2.32 \mathrm{E}+09$ & $1.40 \mathrm{E}+09$ & 1.662272 & 0.1350 \\
\hline \multirow[t]{3}{*}{ ARGEYAT } & 92.71018 & 20.81845 & 4.453269 & 0.0021 \\
\hline & $\mathrm{R}^{2}$ & 0.712557 & F-istatistiği & 19.83161 \\
\hline & Durbin-Watson & 2.039710 & F-Olasılık & 0.002130 \\
\hline \multicolumn{5}{|c|}{ DYO BOYA FABRIKALARI SANAYI VE TICARET A.Ş. } \\
\hline & Katsayılar & Standart Hata & $\mathrm{t}$ istatistiği & Olasılık \\
\hline C & -17528554 & 12163668 & -1.441058 & 0.1875 \\
\hline \multirow[t]{3}{*}{ ARGEYAT } & 45.04952 & 1.343284 & 33.53686 & 0.0000 \\
\hline & $\mathrm{R}^{2}$ & 0.992937 & F-isstatistiği & 1124.721 \\
\hline & Durbin-Watson & 1.490474 & F-Olasılık & 0.000000 \\
\hline \multicolumn{5}{|c|}{ VESTEL ELEKTRONIK SANAYI VE TICARET A.Ş. } \\
\hline & Katsayılar & Standart Hata & $\mathrm{t}$ istatistiği & Olasılık \\
\hline $\mathrm{C}$ & $3.16 \mathrm{E}+09$ & $6.87 \mathrm{E}+08$ & 4.602946 & 0.0017 \\
\hline \multirow[t]{3}{*}{ ARGEYAT } & 40.05304 & 9.962276 & 4.020471 & 0.0038 \\
\hline & $\mathrm{R}^{2}$ & 0.668932 & F-İstatistiği & 16.16418 \\
\hline & Durbin-Watson & 2.271438 & F-Olasılık & 0.003839 \\
\hline
\end{tabular}


Analiz sonuçları incelendiğinde yapılan yatırımları ile Satışlar arasında; Arçelik A.Ş., DYO Boya A.Ş. ve Vestel A.Ş. AKIN Tekstil A.Ş.'inde \%1 önem düzeyinde, AKIN Tekstil A.Ş. ile \%5 önem düzeyinde anlamlı bir ilişkinin olduğu, ancak AKSA Akrilik Kimya Sanayi A.Ş. arasında bir ilişkinin mevcut olmadığı sonucu elde edilmiştir. Bu sonuçtan yola çıkarak Ar-Ge yatırımlarının AKSA Akrilik Kimya Sanayi A.Ş. hariç diğer işletmelerin satışlarını etkilediği anlaşılmaktadır. Ayrıca ele alınan $\mathrm{R}^{2}$ sonuçları da Ar-Ge yatırımlarının Satışları yüksek oranda açıkladığını göstermektedir.

Çalışmada öncelikli gayemiz olan yapılan nanoteknoloji yatırımlarının maliyetlere etkisinin ortaya çıkarılması amacıyla Ar-Ge Yatırımlarının ve Satışların Maliyetinin Satışlara oranının tespiti amacıyla dikey analiz yapılmış ve daha sonra elde edilen sonuçlar 2005 yılı baz yıl alınarak trend analizine tabi tutulmuştur. Yapılan analizler sonucu elde edilen sonuçlar Tablo 3'te sıralanmıştır.

Tablo 3: Trend Analizi

\begin{tabular}{|c|c|c|c|c|c|c|c|c|c|c|}
\hline \multicolumn{11}{|l|}{ AKIN TEKSTIL A.Ş. } \\
\hline & 2005 & 2006 & 2007 & 2008 & 2009 & 2010 & 2011 & 2012 & 2013 & 2014 \\
\hline ARGEYAT/NETSAT & 100 & 115 & 122 & 154 & 126 & 129 & 122 & 207 & 206 & 152 \\
\hline SATMAL/NETSAT & 100 & 90 & 98 & 97 & 90 & 93 & 91 & 100 & 98 & 86 \\
\hline \multicolumn{11}{|c|}{ AKSA AKRILIK KIMYA SANAYii A.Ş. } \\
\hline & 2005 & 2006 & 2007 & 2008 & 2009 & 2010 & 2011 & 2012 & 2013 & 2014 \\
\hline ARGEYAT/NETSAT & 100 & 187 & 285 & 469 & 764 & 288 & 637 & 158 & 370 & 211 \\
\hline SATMAL/NETSAT & 100 & 93 & 95 & 92 & 83 & 89 & 87 & 87 & 85 & 86 \\
\hline \multicolumn{11}{|l|}{ ARÇELIK A.Ş. } \\
\hline & 2005 & 2006 & 2007 & 2008 & 2009 & 2010 & 2011 & 2012 & 2013 & 2014 \\
\hline ARGEYAT/NETSAT & 100 & 142 & 59 & 104 & 96 & 114 & 100 & 91 & 98 & 106 \\
\hline SATMAL/NETSAT & 100 & 97 & 96 & 94 & 88 & 92 & 92 & 93 & 91 & 90 \\
\hline \multicolumn{11}{|c|}{ DYO BOYA FABRIKALARI SANAYI VE TICARET A.Ş. } \\
\hline & 2005 & 2006 & 2007 & 2008 & 2009 & 2010 & 2011 & 2012 & 2013 & 2014 \\
\hline ARGEYAT/NETSAT & 100 & 101 & 94 & 106 & 97 & 92 & 91 & 89 & 91 & 95 \\
\hline SATMAL/NETSAT & 100 & 104 & 96 & 98 & 97 & 97 & 105 & 96 & 89 & 93 \\
\hline \multicolumn{11}{|c|}{ VESTEL ELEKTRONIK SANAYI VE TICARET A.Ş. } \\
\hline & 2005 & 2006 & 2007 & 2008 & 2009 & 2010 & 2011 & 2012 & 2013 & 2014 \\
\hline ARGEYAT/NETSAT & 100 & 101 & 55 & 61 & 104 & 124 & 118 & 87 & 144 & 124 \\
\hline SATMAL/NETSAT & 100 & 98 & 104 & 95 & 95 & 101 & 96 & 103 & 97 & 94 \\
\hline
\end{tabular}

Yapılan dikey analiz ve trend analizi sonuçları değerlendirildiğinde yapılan yatırımların satışlar içerisindeki payı artarken, satışların maliyetinin satışlar içerisindeki payının düştüğü bu durumunda yapılan yatırımlar sonucunda işletmenin maliyetlerinde düşüşe neden olduğu bu nedenle yapılacak yatırımların işletmeler açısından pozitif bir değere sahip olduğu görülmektedir.

\section{DEĞERLENDIRME VE SONUÇ}

Günümüzde nanoteknoloji ile atomlardaki güç keşfedilmiş ve insanoğlu tarafından faydaya dönüştürülmüştür. Mevcut varlıklar nano boyutlarda incelenmiş, bunlardan esinlenerek yeni ürünler icat edilmiştir. İnsanoğlunun yaşamını kolaylaştıran bu ürünler sayesinde 
işletmeler, amaç edindikleri değer ve kâr maksimizasyonunu gerçekleştirirken toplumun refah seviyesi bir adım daha ileriye götürülmüştür. Yazının ilk icat edildiği dönemlerde devasa taşlara yazılan yazılar çağımızda gözle görülemeyen atomlara yazılmış, kütüphaneler dolusu bilgiler atom zerrelerine sığdırılmıştır. Tarih öncesi devirlerden yakın geçmişte yaşayan insanlara kadar, hayal bile edemiyecekleri teknolojiler günümüz insanları tarafından basit bir şey haline gelmiş ve nanoteknolojik gelişmeler ile yeni hayallerin kapıları sonuna kadar açılmışıtır.

Çağımızda bütün devletler ve işletmeler nanoteknolojik buluşun peşine düşmüş; gelişmiş ülkelerin bu konuda yapmış oldukları yatırımlar bazı ülkelerin bütçesini geçmiştir. Buna kayıtsız kalmayan ülkemizin ise yapmış olduğu çalışmalar ve yatırımlar kat be kat artsada, olması gereken düzeyin çok altında kalmıştır. Fakat 2015 yılı itibari ile son 10 yılda bu konuda atak yapan şirketlerimiz rakiplerine karşı bariz bir şekilde önde giderken yeni buluşlar için bu tür yatııımların peşini bırakmamış; her geçen gün daha fazla yatııım yaparak çok önemli bir hazinenin peşinde olduklarını göstermişlerdir.

Bu zamanda bir işletmenin sürdürülebilirliğinin sağlanması için bu tür inovasyonların yapılması bir zorunluluk haline gelmiştir. Bir hazine olarak nitelendirdiğimiz nanoteknoloji ise bu amacın bir tedarikçisi konumundadır. Üretilen nanoteknolojik ürünler hem toplumun en önemli ihtiyaçlarını gidermiş hem de bu çağı bir adım daha ileriye götürmüştür. Nanoteknoloji yatırımları sonucu üretilen ürünler sayesinde ürün maliyetleri düşmektedir. Çünkü hem hammadde daha az kullanılmakta hem enerji tasarrufu sağlanmakta hem de işgücüne daha az ihtiyaç duyulmaktadır. İşletmeler için öncelikli bir hedef olan maliyet düşüşü sağlanırken aynı zamanda daha kaliteli, daha sağlam ve daha tercih edilebilir ürünler ortaya çıkmaktadır.

Çalışmanın uygulama bölümünde BIST'te, ulusal pazarda yer alan ve nanoteknoloji yatııımı yapan beş imalat işletmesinin (Akın Tekstil A.Ş., AKSA Akrilik Kimya ve Sanayii A.Ş., Arçelik A.Ş., DYO Boya A.Ş. ve Vestel A.Ş.) finansal tabloları ele alınarak; korelasyon, regresyon, dikey ve trend analizine tabi tutulmuştur. Yapılan araştırmalar neticesinde yapılan yatırımların maliyetlere etkisi hem bu konuda yapılan uzman görüşleri hem de yapılan analizler sonucunda ortaya konmuştur.

Uzman görüşleri ele alınarak değerlendirildiğinde yapılan yatıımların maliyetlere etkisi kısaca şu şekilde sıralanabilir:

- Üretilen ürünler nano boyutlarda olduğu için daha az hammaddeye ihtiyaç duyulacaktır. Bu da maliyetlere yansıyacak ve maliyetleri azaltacaktır.

- Daha az işgücüne ihtiyaç duyulacağı için maliyetlere olumlu bir şekilde yansıyacaktır.

- İstenen ekipmanların daha az olması maliyetleri olumlu bir şekilde etkilemektedir. Örneğin: Yüzey aplikasyonunda nanoteknolojinin sunduğu gelişmeler ürünün temel doğasını değiştirmemekte, sadece tatmin edici gelişmeler sunmaktadır. Gömlekler halen gömlektir, ancak nanopartiküller onları kirlere karşı daha dayanıklı ve kendi kendine temizlenebilir yapmaktadır. Aplikasyon işlemi fabrikalarda mevcut bulunan işlem ekipmanlarıyla gerçekleştirilebildiği için ilave ekipmana intiyaç yoktur. Böylece yatıım maliyetinden tasarruf sağlanmış olmaktadır (http://kimyaturk.net). 
- Nanokompozitlerde ${ }^{2}$ seri üretime uygun bir şekilde maliyet azaltımı önem arz etmektedir. Bu amaçla Karbon nano tüp uygulamaları polipropilen malzeme ile çalışılmakta, bu şekilde kalıptan renkli, düzgün yüzeyli parçalar elde edilerek, hem fonksiyonelliğin iyileştirilmesi, hem de maliyetlerin düşürülmesi sağlanmaktadır.

- Çelikten daha sağlam, çok hafif, yanmaz ve daha kolay işlenebilir tekstil kompozitleri, günlük hayatta kullandığımız giysiler ve ev tekstilleri dışında, taşıma araçlarından binalara, askeri giysilerden koruyucu ürünlere kadar pek çok alanda önemli işlevler sağlayan bileşenler olmaktadır. Nanoteknoloji ayrıca tekstil üretiminde kullanılan boya ve yardımc kimyasalların daha verimli ve çok daha az kullanılmasını sağlayarak, hem üretim maliyetlerinde, hem de çevre kirliliğinde azalmaya da neden olmaktadır.

- İmalat işletmeleri ürettikleri nanoteknolojik ürünleri daha kısa zamanda üretecekleri için günlük üretim miktarı artmakta ve böylece satışlarda artışa neden olmaktadır.

Yapılan analizlerde ise işletmelerin yapmış oldukları yatırımların satışlarla ve satışların maliyetiyle aralarında yüksek oranda bir pozitif ilişkinin olduğu (AKIN Tekstil A.Ş. hariç), yapılan yatırımlarla satışlar arasında \%1önem düzeyinde anlamlı bir ilişkinin mevcut (AKSA Akrilik Kimya Sanayii A.Ş. hariç) olduğu tespit edilmiştir. Ayrıca trend analizi neticesinde maliyetin satışlara oranındaki düşüşle birlikte Ar-Ge Yatırımlarının Satışlara oranında artış olduğu görülmüştür. Bu durumda yapılan yatırımların maliyetler üzerinde de hissedildiğini ve maliyetleri aşağı doğru çektiğini göstermektedir. Bu nedenle bu tür çalışmalara yatırım yapacak işletmelerin kısa dönemde olmasa da uzun dönemde pozitif anlamda netice alacağı, işletmelerin bu tür inovasyonlar için vakit kaybetmeden başvurması ve işletmelerin yatırımlarını bu alana kaydırarak hem işletmenin, hem ülkenin hem de toplumun yararına yatırımlarda bulunulması gerektiği sonucuna varılmıştır.

\section{KAYNAKLAR}

Abad E. ve diğerleri (2005), Nanodictionary, Collegium Basilea, Basel.

Akın Tekstil, Ürünler, Erişim tarihi: 05.06.2015,

http://www.akintekstil.com.tr/urunler.asp?islem2=katdetay\&KatlD=24\&AnaKatID=24

Anadolu Üniversitesi, Nano Dünya, Erişim tarihi: 14.04.2015

http://www.akillisinif.anadolu.edu.tr/dosyalar/pdf/20080219/33 157.pdf

Bayraktar, H. , Nanoteknoloji, Erişim tarihi:02.04.2015,

http://www.yaklasansaat.com/dunyamiz/bilim ve teknoloji/nanoteknoloji.asp

Bursa-SMMM ODASI, Ar-Ge Harcamalarının Önemi ve Türkiye'deki Durumu, Erişim tarihi: 26.05.2015, http://www.bursa smmmo.org.tr/yazarlar/makaleler/132AGE.pdf

\footnotetext{
${ }^{2}$ Nano kompozitler, nano ölçeğindeki parçacıkların bir matris düzeni içinde polimer gibi standart bir malzemenin içine yerleştirilmesi ile elde edilir. \% 0,5 ile \% 5 arasındaki bir ilave orijinal malzemeye göre önemli avantajlar elde edilmesi için yeterli olmaktadır. Halen bazı nanokompozit malzemeler araçlarda kullanılmaktadır, fakat laboratuarda hala maliyetleri indirme ve özellikleri arttırma yönünde çalışmalar sürmektedir. 2010 yılındaki nanokompozit pazarının 1 milyar Euro civarı olduğu tahmin edilmektedir.
} 
Doğu Marmara Kalkınma Ajansı (MARKA), NanoteknolojiÇalıştayı, Erişim tarihi: 05.05.2015, http://www.marka.org.tr/haber/detay/1812/nanoteknoloji-\%C3\%A7alistayi\%E2\%80\%A6

Dyo, Bir Bilene Sor!, Erişim tarihi: 10.06.2015, http://www.birbilenesorun.com.tr/teknik bilgiler.html

Enerji ve Tabii Kaynaklar Bakanlığı, Bor, Erişim tarihi: 29.05.2015,

http://www.enerji.gov.tr/index.php?sf=webpages\&b=bor\&bn=226\&hn=226\&nm=390\&id=392

Erkoç, Ş. (2012), Nanobilim ve Nanoteknoloji, ODTÜ Yayıncılık, Ankara.

Fikir, Dünyada ve Türkiye'de Nanoteknoloji Yatırımları, Erişim tarihi: 06.05.2015, https://www.fikir.net/nanoteknoloji/1668-dunya-da-ve-turkiye-de-nano-teknoloji-yatirimlari.html

Grupta, T. ve Ahalapitiya H. J. (2003), RecentAdvances in Nanotechnology: Keylssues\&Potential Problem Areas, IEEE-NANO 2003, 2003 Third IEEE Conferenc, Kalamazoo, USA, ss. 469-472.

GYTE, Nanoteknoloji Araştırma Merkezi, Erişim tarihi: 18.05.2015,

http://www.gyte.edu.tr/icerik/57/614/nanoteknoloji--arastirma-merkezi.aspx

Haberler, Nano Halı Buluşu ile Yüzde 350 Büyüyen Atlas Halı, Erişim tarihi: 27.03.2015, http://www.haberler.com/nano-hali-bulusu-ile-yuzde-350-buyuyen-atlas-hali-5813190-haberi/

İstanbul Teknik Üniversitesi, Yatırımlar, Erişim tarihi: 08.05.2015, http://www.nsne.itu.edu.tr/?page id=75

Kimyaturk, Tekstil Endüstrisinde Nanoteknoloji ve Avantajları, Erişim tarihi: 19.06.2015, http://kimyaturk.net/index.php?topic=14419.0

Koç, Türkiye'deki İlkler, Erişim tarihi: 09.06.2015, http://www.koc.com.tr/tr-tr/hakkinda/tarihce/turkiyedekiilkler

Kut, D. ve Güneşoğlu, C. (2005), Nanoteknoloji ve Tekstil Sektöründeki Uygulamaları, Tekstil\&Teknik Dergisi, İstanbul, ss. 224-230.

NNT Nanoteknoloji A.Ş.,Nanoteknoloji ile İşlenmiş Dünyanın İlk Kurşun Geçirmez AluminyumZırh'ını Geliştirdik, Erişim Tarihi: 29.05.2015, http://www.nnt.com.tr/haber-zirh.php

Ornagik Makale, Cırt Cırt Bant Kim İcat Etti, Erişim tarihi: 23.03.2015, http://www.organikmakale.com/tarihbiyografi/cirt-cirt-bant-kim-icat-etti-velcro-bant/

Özdoğan, E. ve diğerleri (2006), Nanoteknoloji ve Tekstil Uygulamaları, Tekstil ve Konfeksiyon Dergisi, İzmir, ss. 159-163.

Özgüz, V. (2012), Türkiye'de Nanoteknoloji Araştırma ve Geliştirme, Nanoteknoloji Araştırma ve Uygulama Merkezi Sunumu, Sabancı Üniversitesi Yayınları, İstanbul.

Para \& Borsa, Aksa çözülemeyen formülün sırrını buldu dünya 9'uncusu oldu, Erişim tarihi: 09.06.2015, http://www.paraborsa.net/i/aksa-cozulemeyen-formulun-sirrini-buldu-dunya-9\%E2\%80\%99uncusu-oldu/

Radikal, Türk Mühendisler Nanoteknolojiyi Uzaya Çıkaracak Malzemeyi Buldu, Erişim tarihi: 28.05.2015, http://www.radikal.com.tr/ekonomi/turk muhendisler nanoteknolojiyi uzaya cikaracak malzemeyi buldu1007865

Ramsden, J. (2011), Nanoteknolojinin Esasları, ODTÜ Yayıncılık, Ankara.

Sabancı Üniversitesi, Neden Sabancı Üniversitesi Nanoteknoloji YL Programı?, Erişim tarihi: 18.05.2015, http://nano.sabanciuniv.edu/tr/neden-sabanci-universitesi-nanoteknoloji-yl-programi

Teknoloji, Monolyx: Çelik Kord Yerine Kullanılabilecek Çok Katı MonofilamanKord Geliştirilmesi, Erişim tarihi: 01.06.2015, http://teknoloji.org.tr/docs/web-poster/84- Layout\%201.pdf

Textotex, Asırlık İpekiş Avrupa'nın Gözdesi, Erişim tarihi: 01.06.2015, http://www.textotex.com/haber/ozelhaber/asirlik-ipekis-avrupanin-gozdesi.html

TUBITAK, Ulusal Destekler ve AB Çerçeve Programları'nda KOBi'ler, Erişim tarihi: 08.05.2015, http://www.fp7.org.tr/tubitak content files/279/Teknopark Bilgi Gunleri/Bahadir ulusaldesteklergazi.pdf 
Vikipedi, Ulusal Nanoteknoloji Araştırma Merkezi, Erişim tarihi: 18.05.2015

http://tr.wikipedia.org/wiki/Ulusal Nanoteknoloji Ara\%C5\%9Ft\%C4\%B1rma_Merkezi

Zorlu, 1994'ten 2009'a Vestel'in Gelişimi, Erişim tarihi: 11.06.2015,

http://www.zorlu.com.tr/tr/GRUP/ves gelisim.asp

Zorlu, Ürün Segmentleri Bazında Gelişmeler, Erişim tarihi: 11.06.2015,

http://www.zorlu.com.tr/tr/GRUP/ves urunsegment.asp

Zorlu, Vestel'de AR-GE, Erişim tarihi: 11.06.2015, http://www.zorlu.com.tr/tr/GRUP/ves_arge.asp 